Computer-Aided

Facilities Planning 


\title{
INDUSTRIAL ENGINEERING
}

\section{A Series of Reference Books and Textbooks}

\author{
Editor \\ WILBUR MEIER, JR. \\ Dean, College of Engineering \\ The Pennsylvania State University \\ University Park, Pennsylvania
}

Volume 1: Optimization Algorithms for Networks and Graphs, Edward Minieka

Volume 2: Operations Research Support Methodology, edited by Albert G. Holzman

Volume 3: MOST Work Measurement Systems, Kjell B. Zandin

Volume 4: Optimization of Systems Reliability, Frank A. Tillman, Ching-Lai Hwang, and Way Kuo

Volume 5: Managing Work-In-Process Inventory, Kenneth Kivenko

Volume 6: Mathematical Programming for Operations Researchers and Computer Scientists edited by Albert G. Holzman

Volume 7: Practical Quality Management in the Chemical Process Industry, Morton E. Bader

Volume 8: Quality Assurance in Research and Development, George W. Roberts

Volume 9: Computer-Aided Facilities Planning, H. Lee Hales 


\section{AN MMPORTANT MESSAGE TO READERS...}

A Marcel Dekker, Inc. Facsimile Edition contains the exact contents of an original hard cover MDI published work but in a new soft sturdy cover.

Reprinting scholarly works in an economical format assures readers that important information they need remains accessible. Facsimile Editions provide a viable altemative to books that could go "out of print." Utilizing a contem. porary printing process for Facsimile Editions, scientific and technical books are reproduced in limited quantities to meet demand.

Marcel Dekker, Inc. is pleased to offer this specialized service to its readers in the academic and scientific communities. 


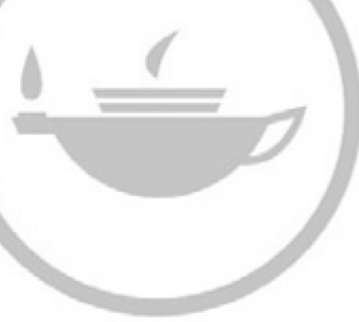

Tayllor \& Francis Taylor \& Francis Group http://taylorandfrancis.com 


\title{
Computer-Aided Facilities Planning
}

\author{
H. LEE HALES \\ Management Consultant \\ Houston, Texas
}


Library of Congress Cataloging in Publication Data

Hales, H. Lee

Computer-aided facilities planning.

(Industrial engineering ; v. 9)

Includes index.

1. Factories--Design and construction--Data processing.

2. Plant layout--Data processing. 3. Facility manage-

ment--Data processing. I. Title. II. Series.

TS177.H35 $1984 \quad 725^{\prime} .4^{\prime} 02854 \quad 84-14249$

ISBN $0-8247-8143-0$

COPYRIGHT $\odot 1984$ by MARCEL DEKKER, INC. ALL RIGHTS RESERVED

Reprinted 2009 by CRC Press

Neither this book nor any part may be reproduced or transmitted in any form or by any means, electronic, or mechanical, including photocopying, microfilming, and recording, or by any information storage and retrieval system, without permission in writing from the publisher.

MARCEL DEKKER, INC.

270 Madison Avenue, New York, New York 10016

Current printing (last digit) :

$\begin{array}{lllllllll}10 & 9 & 8 & 7 & 6 & 5 & 4 & 3 & 2\end{array}$ 


\section{Preface}

This book is for facilities planners and managers. It is a survey of current practice in both planning and computer aids. The ideas and computer applications contained in this book can help you "work smarter," instead of harder, on future planning projects.

I have assumed that you have some familiarity with computers and that you have seen a personal computer, a large mainframe, and probably a large minicomputer. I have also assumed that you know what a computer program is and does, that you have heard about such things as service bureaus and timesharing networks, that you have read about or seen a demonstration of computer-aided design.

We will use a broad definition of "facilities" to include: land and its improvements; buildings and other structures; space within buildings; furniture, equipment, and machinery. In discussing industrial facilities, we will include material handling equipment.

We will view facilities planning as one stage in the facilities management cycle. This cycle, depicted in the figure, encompasses the provision or construction of facilities, as well as their ongoing review and management.

Facilities planning is a broad endeavor that cuts across other disciplines of planning, engineering, and design. To keep this book manageable, it has been necessary to limit its scope where these allied disciplines are concerned. We will not cover the use of computers for such engineering tasks as structural analysis, electrical schematics, piping design, civil engineering, and energy simulation. The planning of industrial facilities is sometimes inseparable from process and methods planning. Computer-aided process planning, however, is a subject unto itself, and will not be covered here. I have taken the same position with respect to computer simulation of materials handling and production systems. While simulation is an indispensible tool in certain facilities planning tasks, it is also a field of its own and is already the subject of many books.

The scope of this book, then, is largely confined to space projections, block and detailed layout planning, material flow analysis, plan and elevation drawings--the core activities of most facilities planners. The management of the planning project and of the facility itself are also covered.

You will be a much better planner if you systematize first, and computerize second. For this reason, Part $I$ is about facilities planning. In it I have 


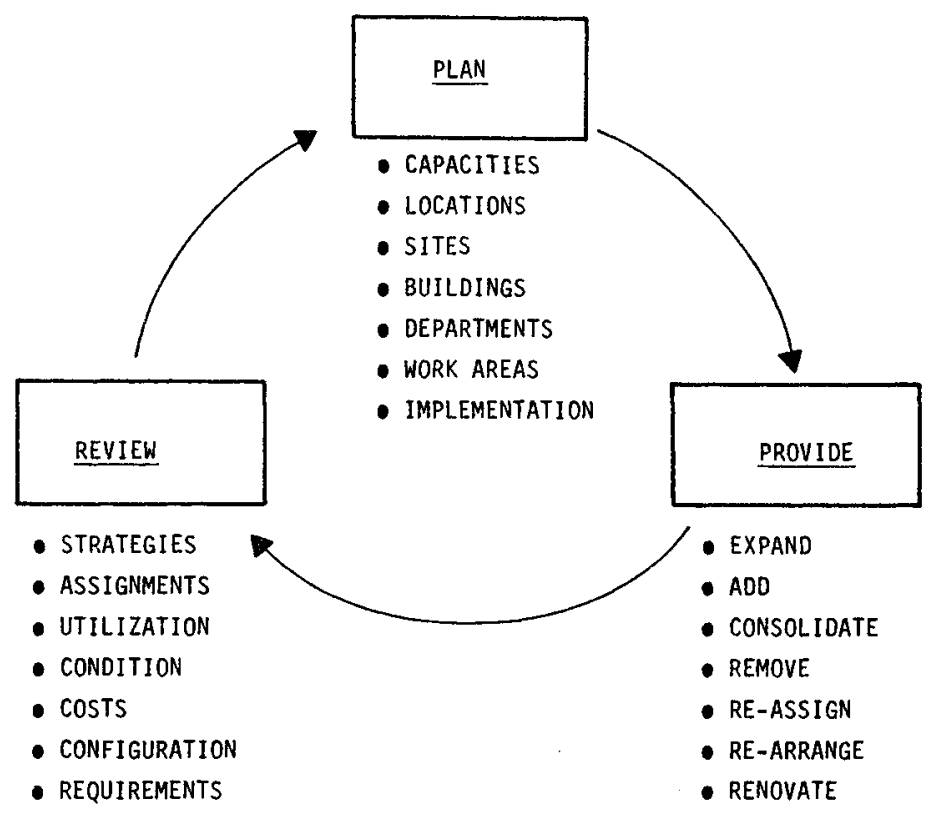

The facilities management cycle.

outlined the kinds of systematic planning approaches and techniques that lend themselves well to computer support. My experience suggests that the computer will not make you systematic although it will force you in that direction. The computer will make you better and rapidly more effective if you already have good manual approaches. For this reason, I urge you to read Part I carefully and compare your present practices to the methods it describes.

Part II is about computers--describing what is available, and providing typical examples of computer-aided facilities planning. Part II is a survey. It covers a wide range of applications in layout planning, space estimating, design and drafting, inventories, etc. We will discuss the purpose and benefits of these applications. Inner workings will be covered only as required to understand the strengths and weaknesses of a particular computer aid. We will not look at code, or programming, or the inner workings of computer equipment.

I have limited Part II almost exclusively to commercially available software and systems. With dozens of proven products available there is little need today to develop one's own. Internal development efforts should generally be limited to the construction of large data bases, specialized facilities management systems, or the development of links between separately sourced systems and programs.

Part III is about implementation. Finding computer aids is easy; there are a great many around. Others are easily developed. But getting them installed and achieving good results is often another story. In Part III, I have compiled checklists and pointers from past installation efforts. If observed, you have a good chance of avoiding others' mistakes. .

Finally, in Part IV, I have included two appendixes--one on information sources and a second on consultants--and a reference section. I do not claim 
completeness for these materials. They have been compiled from my personal experience and my awareness of what others are doing. Because this book is a survey of a rapidly changing field, Part IV will help you keep current and gain additional depth in the areas of your primary interest.

I first outlined this book in December 1980. Had I written it then, it would be hopelessely obsolete today. Such is the pace of change in computer-aided facilities planning. The past three years have brought the amazing spread of personal computers; the electronic spreadsheet, making it easy to "program" many routine tasks; integrated software combining spreadsheets, graphics, and word processing; and the 32-bit microprocessor, dropping the price of computer-aided design systems from $\$ 100,000$ to as low as $\$ 25,000$.

During this time we have also seen the formation and growth of new professional groups devoted to facilities planning: the International Facility Management Association, the Society of Property Administrators, the Organization of Facilities Managers and Planners. Each of these groups has provided a forum for the discussion and spread of computer aids. New journals have also appeared such as Computers in Design and Construction, Facilities Design and Management, and Corporate Design, each devoting space to computer aids and case studies.

I am convinced that facilities planners are just beginning to make effective use of computers. The price of dedicated devices is now within our reach. Computers are also much easier to use. And, with these new forums available, the spread of computer aids should be very rapid indeed. While this book includes current applications, I am sure some exciting new ones will come along in the future. Appendix A has been included to help you keep up with these developments yet to come. 


\section{Acknowledgments}

I had the good fortune to learn facilities planning from Richard Muther, working in his consulting firm for eight years. We also coauthored two books. The first was a brief survey of office space planning. The second was a twovolume, 600-page book, Systematic Planning of Industrial Facilities. One does not write a 600-page technical book without drawing on it heavily in subsequent works. So you will find that much of Part $I$ here is written around the Richard Muther techniques as described in our joint efforts, and in his earlier wellknown works on facilities planning.

In 1980, I went to the Massachusetts Institute of Technology, spending much of the year studying computers. During this time $I$ met and learned from some true pioneers in the field of computer-aided facilities planning.

From Kreon Cyros, M.I.T.'s director of facilities management systems, I learned about large-scale information systems and data base design. Software developed by Kreon Cyros and his staff is currently used to manage millions of square feet in universities, hospitals, offices, and plants. While living in Boston, I was able to spend time with John Nilsson, an M.I.T. graduate and early pioneer in computer-aided architectural design. As president of Decision Graphics in Southboro, Massachusetts, John Nilsson shared with me his great knowledge of CAD and its evolution in architecture and facilities planning.

My research at M.I.T. led me to Howard Berger, founder of Micro-Vector, Inc., in Armonk, New York. From him I learned about the surprising power of personal and microcomputers when applied to facilities planning. Since the early 1970s, Howard Berger has written dozens of programs. He is one of the most creative and prolific software writers I know. His programs have been used by a variety of professionals to plan millions of square feet.

In New York, I also met and learned from Marshall Graham, senior vice president of Environetics International, one of the first firms to apply computer-aided design to interior layout planning. Marshall Graham and his staff have been practicing computer-aided facilities planning for more than 10 years.

Still another New Yorker, Allan Cytryn, amazed me with his algorithms for multistory and block layout planning. Currently running on an Apple Ile, they are the latest in a series of programs that originally required large mainframe computers.

I have learned the most about algorithms from James $M$. Moore, president 
of Moore Productivity Software in Blacksburg, Virginia. As a professor and consultant, Jim Noore has developed encyclopedic knowledge of algorithms, their origins, and inner workings. He is the developer of CORELAP, one of the most widely used algorithms for plant layout. Fortunately for us all, Jim Moore shares his knowledge through prolific writings on computer-aided facilities planning.

Recently I had the good fortune to work with David Arrigoni and David Albert at Arrigoni Computer Graphics. Since the mid 1960s, David Albert has contributed to the development of several popular CAD systems. He is currently president of Vulcan Software, Inc., in Campbell, California. David Arrigoni pioneered the development of low-cost, easily used CAD systems for architectural drafting. Both of these men shared their knowledge and experience with me.

My recent consulting work led me to Dennis and Rose Erickson, president and vice president respectively of BASICOMP, Inc., in Mesa, Arizona. The Ericksons and their staff are a remarkable team. They have spent years perfecting a variety of low-cost aids to interior design and facilities planning.

Two others deserve special mention. First, Harvey Jones, Jr., friend and fellow student at M.I.T., who suffered my ignorance of bits and bytes while we wrote a thesis together on computers. Harvey brought me up to speed with patience and much repetition. He is now senior vice president, marketing, for Daisy Systems Corporation. And finally, my wife, Pamela--the real force behind this book. After two years of hearing about it, she said "Publish or perish!" And she still loved me enough to type the manuscript. No, we don't have a home computer... yet. 


\section{Contents}

Preface

Acknowledgments vi

Part I

HOW FACILITIES ARE PLANNED

1. An Organized Approach to Planning

2. Data Collection and Survey Techniques

3. Systematic Planning Techniques

Part II

HOW COMPUTERS CAN HELP

4. Uses of Computer Technology

5. Computer-Aided Layout Planning $\quad 79$

6. Personal Computer Applications 111

$\begin{array}{ll}\text { 7. Computer-Aided Design (CAD) } & 169\end{array}$

8. Management Information Systems (MIS) Applications 211

Part III

HOW TO ACHIEVE SUCCESS

9. Selecting and Developing Computer Aids 261

$\begin{array}{ll}\text { 10. CAD Selection and Installation } & 279\end{array}$

11. Managing Computer Resources 301

Part IV

HOW TO LEARN MORE

$\begin{array}{lll}\text { Appendix A Information Sources } & 309\end{array}$

Appendix B Consultants 313

$\begin{array}{lr}\text { References } & 317\end{array}$

$\begin{array}{ll}\text { Index } & 321\end{array}$ 


\section{Part I}

HOW FACILITIES ARE PLANNED 


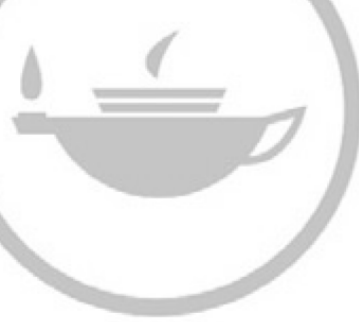

Tayllor \& Francis Taylor \& Francis Group http://taylorandfrancis.com 


\section{An Organized Approach to Planning}

\section{Levels of Planning Decisions}

Facilities plans and decisions are made at several levels. The highest, most abstract decision level is that of capacity planning--providing enough productive capacity of all kinds to meet the needs of the organization. At some point, this capacity must be related to specific quantities and conditions of floorspace, land, buildings and equipment.

From overall capacity decisions, the planner moves "down" to locstions--the geographic placement of capacity. At this level, site planning or land use decisions are made, followed by building decisions covering both the interior and the structure or shell.

Next comes the "department level," where decisions involve groups of people and equipment and their day-to-day activities. Once group or department level decisions are set, the planner looks at workplace design. Finally, plans are made to implement the foregoing decisions.

In practice, of course, there is considerable overlap. It is desirable, but not necessary, to proceed in rigorous "top-down" sequence, but the decisions made at any level must be compatible with those at other levels. Figure 1.1 illustrates the levels of planning. Note the slight variation in issues among the different types of facilities.

\section{Facilities Planning Phases}

In addition to levels, let us also introduce the concept of facilities planning phases. Each planning project can be said to move from some existing facilities or conditions to some future stage of development or desired conditions. The project is accomplished by proceeding logically through a sequence of planning phases. Each phase addresses a different level of planning and decision.

The phases overlap in recognition of the need to integrate the decisions made at different levels of planning. The concept of phases is illustrated in Figure 1.2 and defined further in Figure 1.3.

The difference between overall (Phase II) and detailed (Phase III) planning needs to be stressed. Overall planning focuses primarily on form and 


\begin{tabular}{|c|c|c|c|c|}
\hline \multirow[b]{2}{*}{$\begin{array}{l}\text { LEVEL OF } \\
\text { PLANNING }\end{array}$} & \multirow[b]{2}{*}{ GENERAL ISSUES } & \multicolumn{3}{|c|}{ SPECIFIC ISSUES } \\
\hline & & $\begin{array}{l}\text { INDUSTRIAL } \\
\text { SETTINGS }\end{array}$ & $\begin{array}{l}\text { ADMINISTRATIVE } \\
\text { SETTINGS }\end{array}$ & $\begin{array}{l}\text { INST ITUTIONAL } \\
\text { SETTINGS }\end{array}$ \\
\hline CAPACITY & $\begin{array}{l}\text { Rate of output. } \\
\text { Amount of space. } \\
\text { Make or buy. } \\
\text { Subcontracting. } \\
\text { Own or lease. }\end{array}$ & $\begin{array}{l}\text { Production rates. } \\
\text { Number of shifts. } \\
\text { Degree of auto- } \\
\text { mation. Methods. }\end{array}$ & $\begin{array}{l}\text { Space standards. } \\
\text { Types of furnish- } \\
\text { ings. Interior } \\
\text { concepts. }\end{array}$ & $\begin{array}{l}\text { Number, size and } \\
\text { duration of } \\
\text { programs and } \\
\text { projects. Limits } \\
\text { to growth. }\end{array}$ \\
\hline LOCATIONS & $\begin{array}{l}\text { Number of sites. } \\
\text { Geographic } \\
\text { locations. } \\
\text { Utilities. }\end{array}$ & $\begin{array}{l}\text { Transportation. } \\
\text { Labor costs. } \\
\text { Zoning. Taxes. }\end{array}$ & $\begin{array}{l}\text { Rental rates. } \\
\text { Convenierice. } \\
\text { Labor costs. }\end{array}$ & $\begin{array}{l}\text { Acquisition of } \\
\text { adjoining } \\
\text { property for } \\
\text { growth. Zoning. }\end{array}$ \\
\hline SITES & $\begin{array}{l}\text { Access/egress. } \\
\text { Traffic patterns. } \\
\text { Space allocation. } \\
\text { Future growth. }\end{array}$ & $\begin{array}{l}\text { Topography. } \\
\text { Ratio of yard to } \\
\text { underroof space. }\end{array}$ & $\begin{array}{l}\text { Aesthetics. } \\
\text { Solar energy. }\end{array}$ & $\begin{array}{l}\text { Density. } \\
\text { Aesthetics. }\end{array}$ \\
\hline BUILOINGS & $\begin{array}{l}\text { Size, orientat- } \\
\text { ion and placement } \\
\text { on site. Type of } \\
\text { structure. } \\
\text { Possible future } \\
\text { uses. }\end{array}$ & $\begin{array}{l}\text { Bay size. } \\
\text { Clearances. } \\
\text { Floor strengths. } \\
\text { Utilities. } \\
\text { Flow patterns. }\end{array}$ & $\begin{array}{l}\text { Building module. } \\
\text { Number of floors. } \\
\text { Size of floors. } \\
\text { Exterior finish. } \\
\text { Aesthetics. }\end{array}$ & $\begin{array}{l}\text { Degree of } \\
\text { specialization. } \\
\text { Recycling and } \\
\text { reuse of existing } \\
\text { facilities. } \\
\text { Aesthetics. }\end{array}$ \\
\hline DEPARTMENTS & $\begin{array}{l}\text { Effective use of } \\
\text { space. Proper } \\
\text { placement of } \\
\text { people and } \\
\text { activities. }\end{array}$ & $\begin{array}{l}\text { Work flow. } \\
\text { Production } \\
\text { methods and } \\
\text { equipment. } \\
\text { Materials hand- } \\
\text { ling. }\end{array}$ & $\begin{array}{l}\text { Communications } \\
\text { patterns. Report- } \\
\text { ing relationships }\end{array}$ & $\begin{array}{l}\text { Communications } \\
\text { patterns. Report- } \\
\text { ing relationships } \\
\text { Location of } \\
\text { specialized } \\
\text { equipment. }\end{array}$ \\
\hline WORK AREAS & $\begin{array}{l}\text { Individual } \\
\text { workplace } \\
\text { productivity. }\end{array}$ & $\begin{array}{l}\text { Methods and } \\
\text { standards. } \\
\text { Materials } \\
\text { handl ing. Safety. } \\
\text { Workplace layout. }\end{array}$ & $\begin{array}{l}\text { Systems and } \\
\text { procedures. } \\
\text { Furniture } \\
\text { specifications. } \\
\text { Status. } \\
\text { Appearance. }\end{array}$ & $\begin{array}{l}\text { Systems and } \\
\text { procedures. } \\
\text { Schedul ing, } \\
\text { placement and } \\
\text { control of } \\
\text { special ized } \\
\text { equipment. }\end{array}$ \\
\hline IMPLEMENTATION & $\begin{array}{l}\text { Budgets. } \\
\text { Sequencing. } \\
\text { Timing. }\end{array}$ & $\begin{array}{l}\text { Schedules. } \\
\text { Lost production. }\end{array}$ & $\begin{array}{l}\text { Schedules. } \\
\text { Disruption. }\end{array}$ & $\begin{array}{l}\text { Schedules. } \\
\text { Disruption. }\end{array}$ \\
\hline
\end{tabular}

Figure 1.1. Levels of facilities planning.

the arrangement of facilities. It addresses major operating activities and key economic issues. Detailed planning focuses primarily on the position and placement of dimensioned objects to realize an overall concept or plan.

Consider the planning of a corporate office building. Deciding to use a precast concrete, multistory structure is a Phase II decision. So too is the decision to place Finance next to the Executive Offices on the top floor. Positioning the receptionist's desk to face the elevator is a detailed (Phase III) decision. So too is the placement of lighting, electrical, and telephone outlets to serve the receptionist's desk.

\section{The Process of Planning Facilities}

Putting together our levels and phases, we arrive at the process of planning shown in Figure 1.4. This basic process can be followed for any facility, 


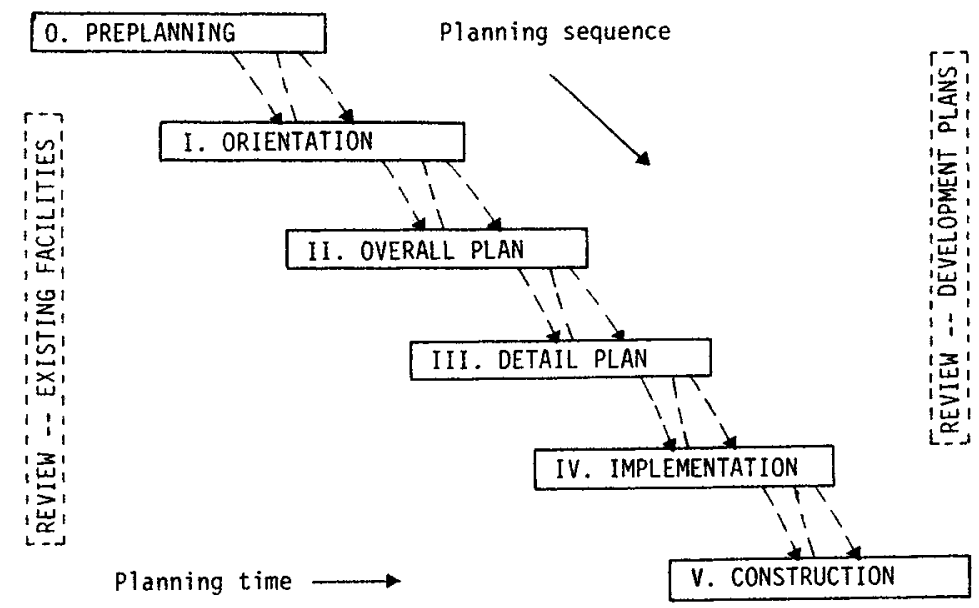

Figure 1.2. Facilities planning phases defined by Richard Muther. Phases I through IV represent pure, facilities planning activities. Phase $O$ represents the on-going interface with business or corporate planning. Phase $\mathrm{V}$ is actual construction, renovation or installation. These phases are "framed" by the on going review of existing facilities, future requirements and standing facilities plans.

\begin{tabular}{|c|c|c|c|c|}
\hline PHASE & SPIF NAME & ACTION & RESULT/OUTPUT & GENERAL TERMINOLOGY \\
\hline 0 & Preplanning & Preplan & $\begin{array}{l}\text { Stated Needs of the } \\
\text { Business }\end{array}$ & Business Planning \\
\hline $\begin{array}{c}-- \\
I\end{array}$ & $\begin{array}{l}----- \\
\text { Orientation }\end{array}$ & $\begin{array}{l}---- \\
\text { Localize }\end{array}$ & $\begin{array}{l}\text { Determined Location } \\
\text { and External Con- } \\
\text { siderations }\end{array}$ & $-----\cdots-\cdots$ \\
\hline$I I$ & $\begin{array}{l}\text { Overa11. } \\
\text { Plan }\end{array}$ & $\begin{array}{l}\text { Plan the } \\
\text { Whole }\end{array}$ & $\begin{array}{l}\text { Overall Plan } \\
\text { (Solution in } \\
\text { Principle) }\end{array}$ & $\begin{array}{l}\text { Physical } \\
\text { Facilities }\end{array}$ \\
\hline III & $\begin{array}{r}\text { Detail } \\
\text { Plans }\end{array}$ & $\begin{array}{l}\text { Plan the } \\
\text { Parts }\end{array}$ & $\begin{array}{l}\text { Detail Plans } \\
\text { (Solution in } \\
\text { Detail) }\end{array}$ & \\
\hline IV & $\begin{array}{l}\text { Implemen- } \\
\text { tation } \\
\text { Planning }\end{array}$ & $\begin{array}{l}\text { Plan the } \\
\text { Action }\end{array}$ & $\begin{array}{l}\text { The Plan for } \\
\text { Implementation }\end{array}$ & \\
\hline V & $\begin{array}{l}\text { Execution } \\
\text { of Plans }\end{array}$ & Act/Do & $\begin{array}{l}\text { The Facility Completed, } \\
\text { Ready to Operate }\end{array}$ & $\begin{array}{l}\text { Constructing, } \\
\text { Rehabilitating, } \\
\& / \text { or Installing }\end{array}$ \\
\hline
\end{tabular}

Figure 1.3. Extended framework of phases summary with planning phases defined. (From Ref. 8, Vol. 1. Copyright 1979, Richard Muther.)

regardless of type. Only the specific techniques and decisions within each phase will vary, depanding upon the type of facility--industrial, administrative, institutional, or other. 


\section{Phase O - PREPLANNING}

- Compile Basic Needs--(Company policy, business plans, and general goals)--and forecast non-physical requirements (What do we want?)

- Evaluate Existing Facilities (What do we have now?)

- Forecast Plan for Capacity Requirements--sizing, dimensioning, conceptual plans... (What do we need?)

- Check for Feasibility (Is it economical to go after the need?)

- Develop a Project Plan--Breakdown of phases, steps, responsibilities, and schedule-- (How will we plan to go after the need?)

\section{Phase I - ORIENTATION}

- Convert the non-facility objectives and existing conditions to physical facility requirements.

- Locate the site, the facility(ies) on the site, or the department in the plant, and identify its external opportunities and constraints.

\section{Phase II - OVERALL PLAN}

- Convert the physical requirements into overall plan of physical facilities--that is, plan the overall facility.

- Establish a solution in principle.

\section{Phase III- DETAIL PLANS}

- Convert the physical requirements and physical constraints for subdivided areas or components of the overall plan into more detailed facilities.

- Establish solutions in detail--details of major features.

Phäse IV - IMPLEMENTATION

- Convert the plans of physical facilities into a program of action; planning the "Do".

- Plan the construction, renovation, and/or installation.

Phase $V$ - CONSTRUCTION, RENOVATION AND/OR INSTALLATION

Follow-up or carrying out of the planning

Figure 1.4. The process of planning. (Courtesy of Richard Muther \& Associates, Inc., Kansas City, Missouri.)

The Five Components of a Facility

One final concept is necessary to completely organize our approach. Within each planning phase, it is very useful to distinguish the different parts of the facility that must be planned or designed.

We can do this very easily with Richard Muther's five components. These are: 
1. Layout: the arrangement of activities, features, and spaces around the relationships that exist between them

2. Handling: the methods of moving products, materials, people and equipment between various points in the facility

3. Communications: the means of transmitting information between various points in the facility

4. Utilities: the conductors and distribution of substances like water, waste, gas, air, and power

5. Building: the form, materials, and design of the structure itself.
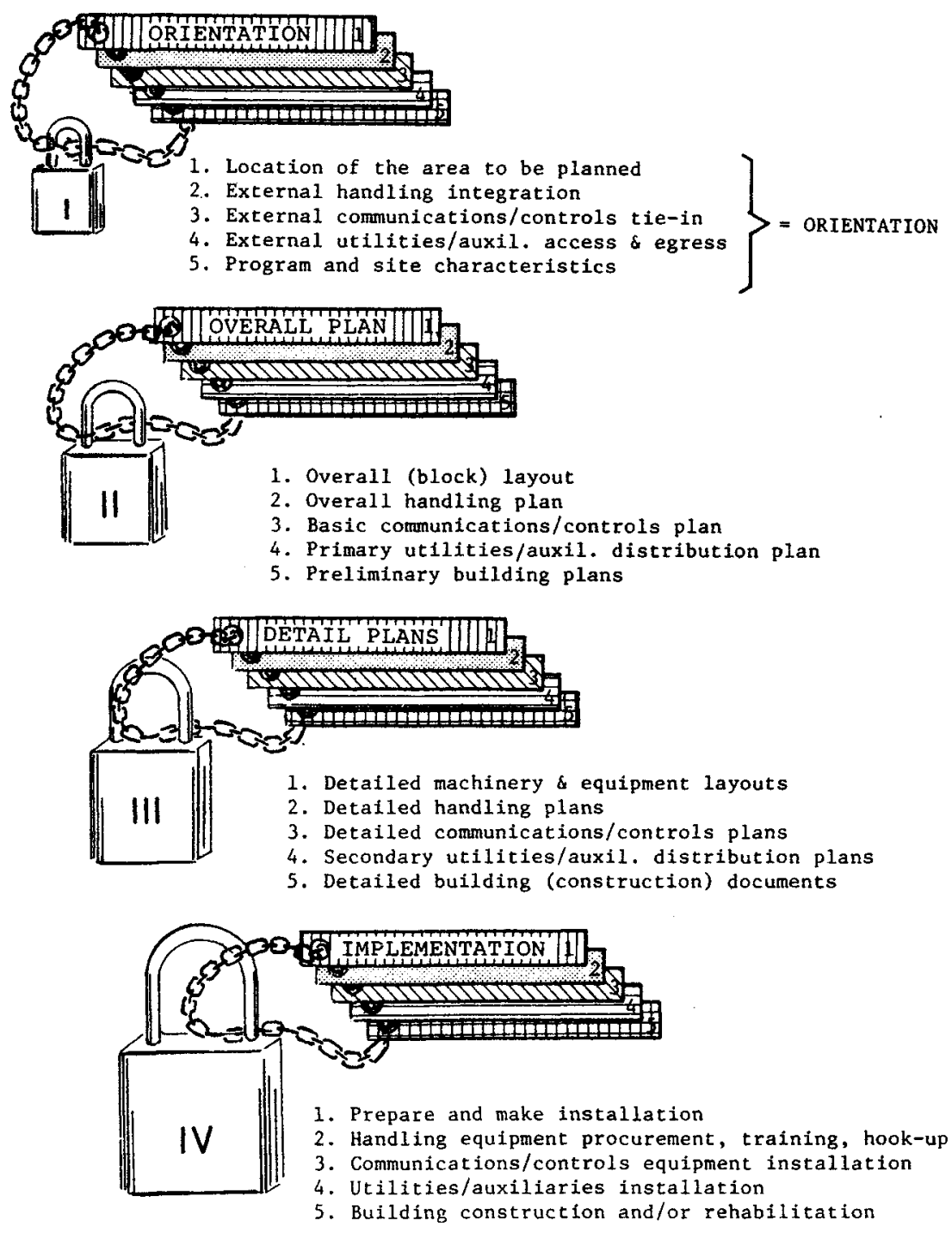

Figure 1.5. All five components are coordinated and approved (locked) at each planning phase. (From Ref. 8, Vol. 1. Copyright 1979, Richard Muther.) 
These components are often planned by different parties in a project team, representing the different professional points of view. By recognizing the need to make "component decisions," we can "lock together" our planning efforts by phase and level, as shown in Figure 1.5.

\section{The Economic Consequences of Facilities Planning}

Facilities decisions can have a direct and lasting impact on financial resources and operating efficiency. An expensive plan or design will consume extra cash or incur extra debt during its construction. An inefficient plan or design will consume extra cash over its entire life. A shortsighted plan will often be shortlived. This may require expensive adjustments later that should have been avoided.

It turns out that the economic consequences of facilities planning can be related directly to the phases we introduced earlier. In Figure 1.6, we see two curves representing the consequences of planning. On the one hand, we have resources invested which rise rapidly during detailed planning and construction. On the other hand we have influence on profit and operating efficiency which is greatest during preplanning and falls off as decisions and designs become firm. The influence curve declines because the level of decision declines in each successive phase.

Capacity decisions (preplanning) have the greatest influence on profit. Too much can be a fatal drag, too little and the market may get away.

Location decisions (orientation) are the next greatest influence. The best site plan, the best building design, can be of little value if the facility is poorly located. On the other hand, the best location may not overcome inadequate or excessive capacity.

Similarly, the best workplace designs may not overcome the inefficiencies of poor departmental placements in the overall plan.

The Key Issues in Facilities Planning

We can summarize our discussion of econornic consequences by listing the key issues in facilities planning.

Size of facilities: maximum and minimum practical sizes in terms of operating cost, organizational effectiveness, exposure to risk, etc.

Location of facilities: stay or move; expand existing locations, or start new ones. Where?

Site missions: assignments and allocation of activities among sites. Roles of each site. Focus of each site or facility .

Financial position: lease or buy. Modernize or build new. Over-build or under-build. When?

Operating efficiency and profit: flexibility, adaptability. Proper configuration and arrangement.

Clearly, the issues above are economic in nature and impact. The manner in which they are resolved is important and requires a sound approach. 


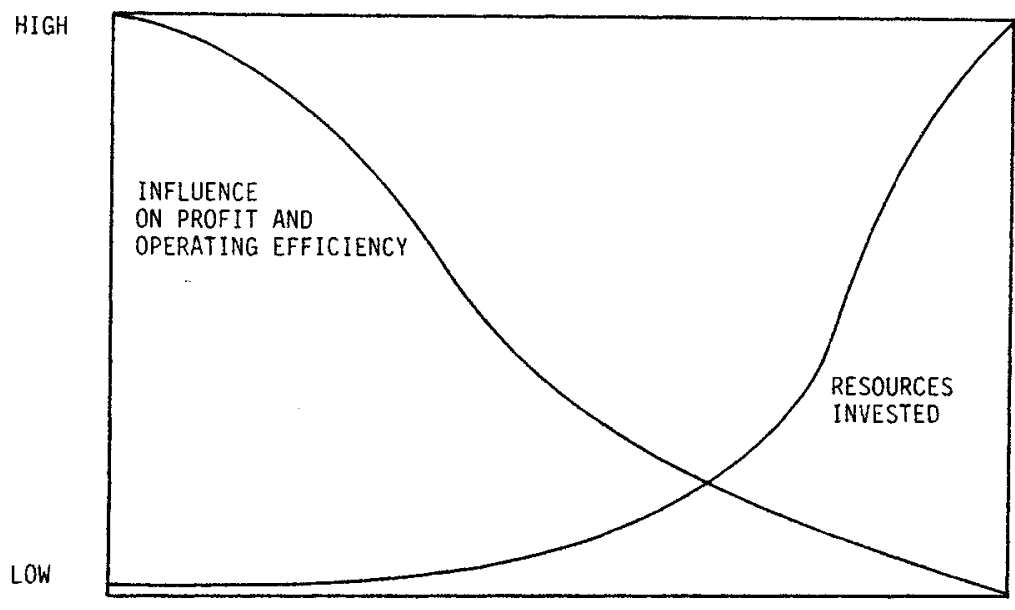

0. PREPLANNING

I. ORIENTATION

II. OVERALL PLAN

III. DETAIL PLAN

IV. IMPLEMENTATION

Systematic planning phases

V. CONSTRUCTION

Figure 1.6. The economic consequences of facilities planning.

\section{Organizational Settings}

Who resolves key issues? Typically it is a team effort. Members of the team vary, depending upon the project and type of facility being planned. Figure 1.7 shows some of the many different parties that may be on the team.

In general, we may view facilities planning and management as being internally and externally provided. Most organizations use both sources. Internal efforts are provided by central (headquarters) and "on-site" (satellite) staffs. External efforts are provided by specialized consultants, design and engineering firms, and contractors and developers.

\section{Facilities Planning in Large Corporations}

Large corporations have rather complex organizational approaches to facilities planning. These merit special attention.

Corporations involve both line managers and staff specialists in reaching facilities decisions. The roles played by line and staff are outlined in Figure 1.8, 


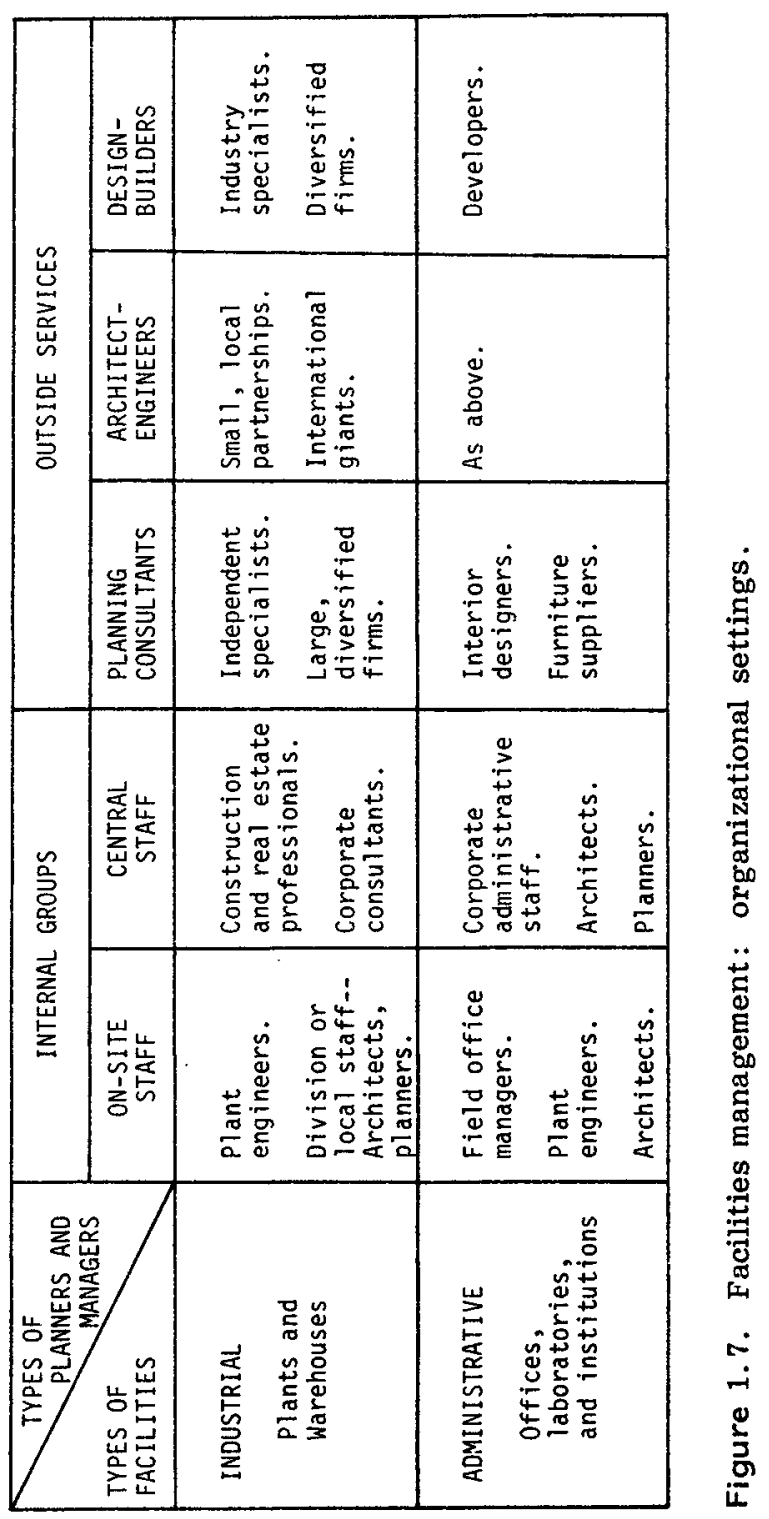




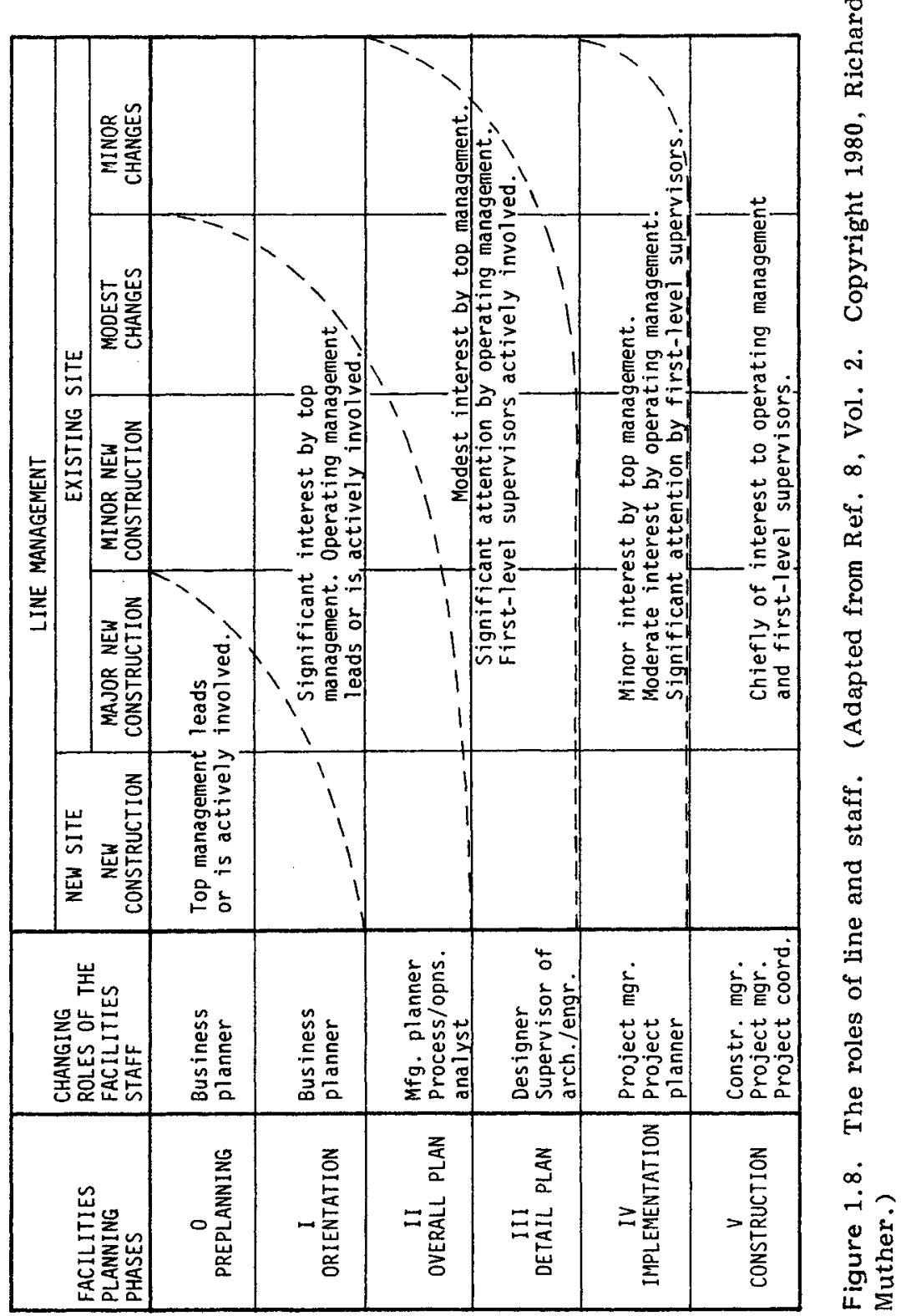


by planning phase and by scope of project. While facilities planning is generally a staff activity, the decisions to adopt or change a plan are typically made by various levels of line management. This is almost always the case with industrial facilities. The distinction is less clear in administrative settings.

The interest and involvement of top management is naturally greatest when new sites and major investments are involved. A top manager may even lead the effort. As a rule, the interest and involvement of top management drops off rapidly after the early phases of a project.

The interests of middle-level, operating managers and first-level supervisors are similarly, but less significantly, correlated with phases and scope of project.

Note the different roles played by the "facilities staff" in Figure 1.8, as a project moves from Preplanning through Construction. Some of these roles may be externally provided by consultants, architects and contractors, as suggested earlier in Figure 1.7.

Virtually every large corporation has at least one top staffer in the corporate offices to advise top management on key issues, and to lead or participate with staff specialists in reaching downstream, field-level decisions.

Typical staff rolls for industrial and administrative settings are shown, by phase, in Figures 1.9 and 1.10. The nature of manufacturing organizations-geographically decentralized along product lines--often leads to more levels of staff and decision-making in facilities planning projects.

The typical roles illustrated here presuppose that an outside or external architect-engineer will be retained for Phase II and III. This work may be preformed by staff architects in large corporations. It is also pre-supposed that local, on-site staff ("Plant Engineer" or "Facilities Manager") will plan and manage the implementation and construction phases of the project.

\section{Shared-Site or Area Staff Groups}

It is quite common in large corporations to find two or more profit centers or business units occupying a single site, or even a single building. Where this occurs, there is a real need to coordinate and integrate the "claims" of each upon the facility.

This need is addressed in one of two ways. Most often, the largest business in a facility acts as a landlord for the smaller ones. The facilities decisions of all units are interrelated, so the largest unit ends up doing the longerrange planning for the smaller ones, insofar as the facilities are concerned.

The other approach is to create a special facilities organization acting as landlord for all the businesses present--both large and small. This facilities group then reports to a line manager well up in the organization--high enough to resolve the inevitable conflicts that occur.

\section{Property Management Divisions}

Some of the largest U.S. corporations, especially financial and service firms, have a subsidiary property management or real estate division which owns the company facilities and provides planning services to its "tenants." This is done for a variety of financial and operating reasons, especially with office buildings, where portions may be leased to outsiders. 


\begin{tabular}{|c|c|c|c|c|c|c|}
\hline \multicolumn{2}{|c|}{ 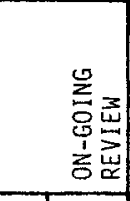 } & 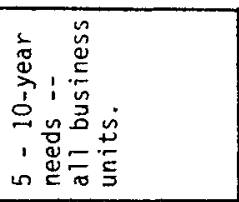 & 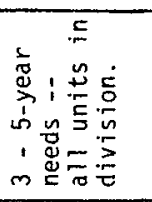 & 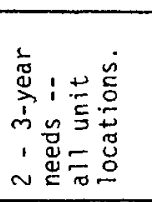 & 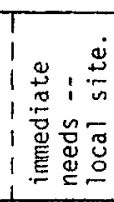 & 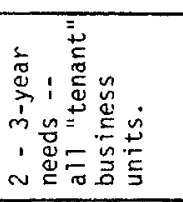 \\
\hline \multirow{6}{*}{ 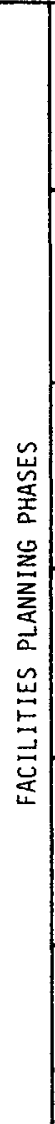 } & 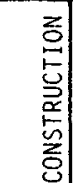 & 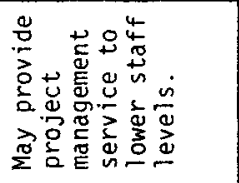 & 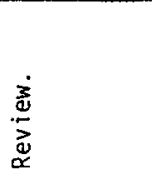 & 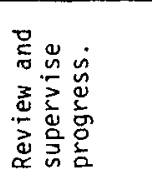 & 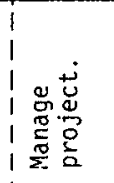 & 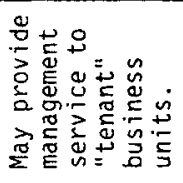 \\
\hline & 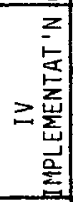 & 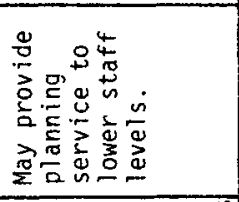 & 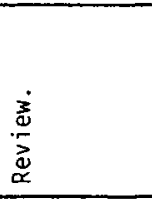 & 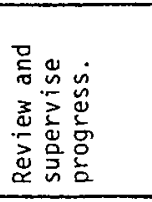 & 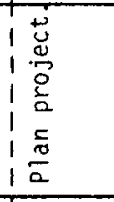 & 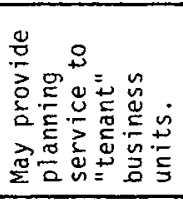 \\
\hline & 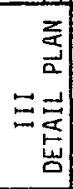 & 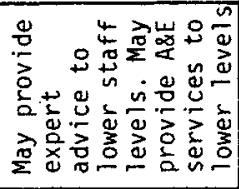 & 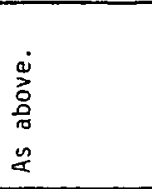 & 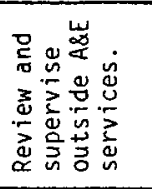 & 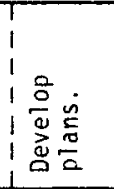 & 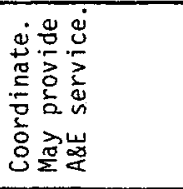 \\
\hline & 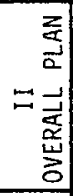 & 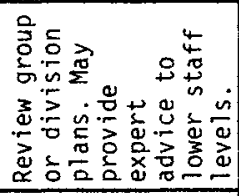 & 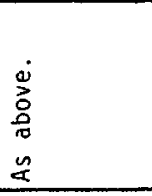 & 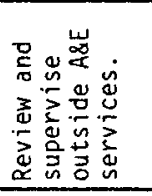 & 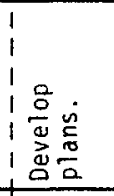 & 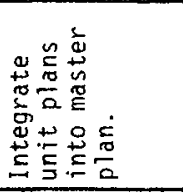 \\
\hline & 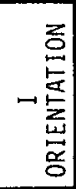 & 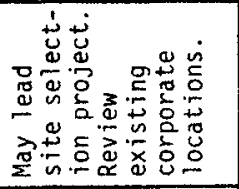 & 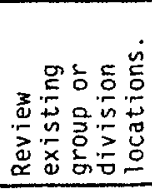 & 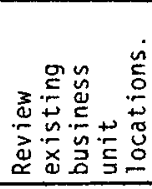 & 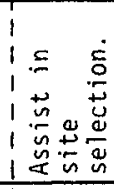 & 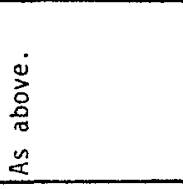 \\
\hline & 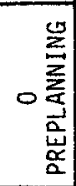 & 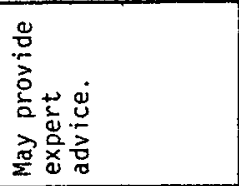 & $\begin{array}{l}0 \\
2 \\
0 \\
0 \\
0 \\
0 \\
0\end{array}$ & 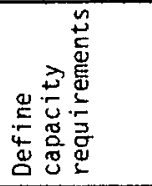 & $\begin{array}{l}1 \\
1 \\
1 \\
\dot{0} \\
2\end{array}$ & $\begin{array}{l}\dot{0} \\
\text { Ė } \\
\text { L }\end{array}$ \\
\hline \multicolumn{2}{|c|}{ 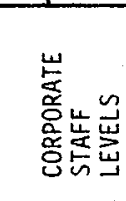 } & 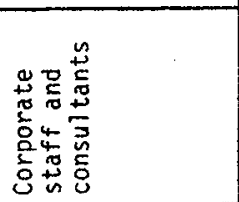 & 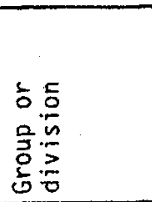 & 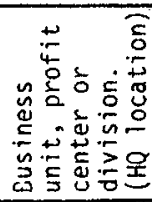 & 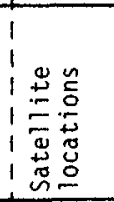 & 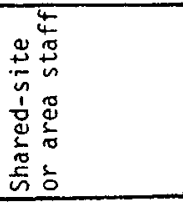 \\
\hline
\end{tabular}




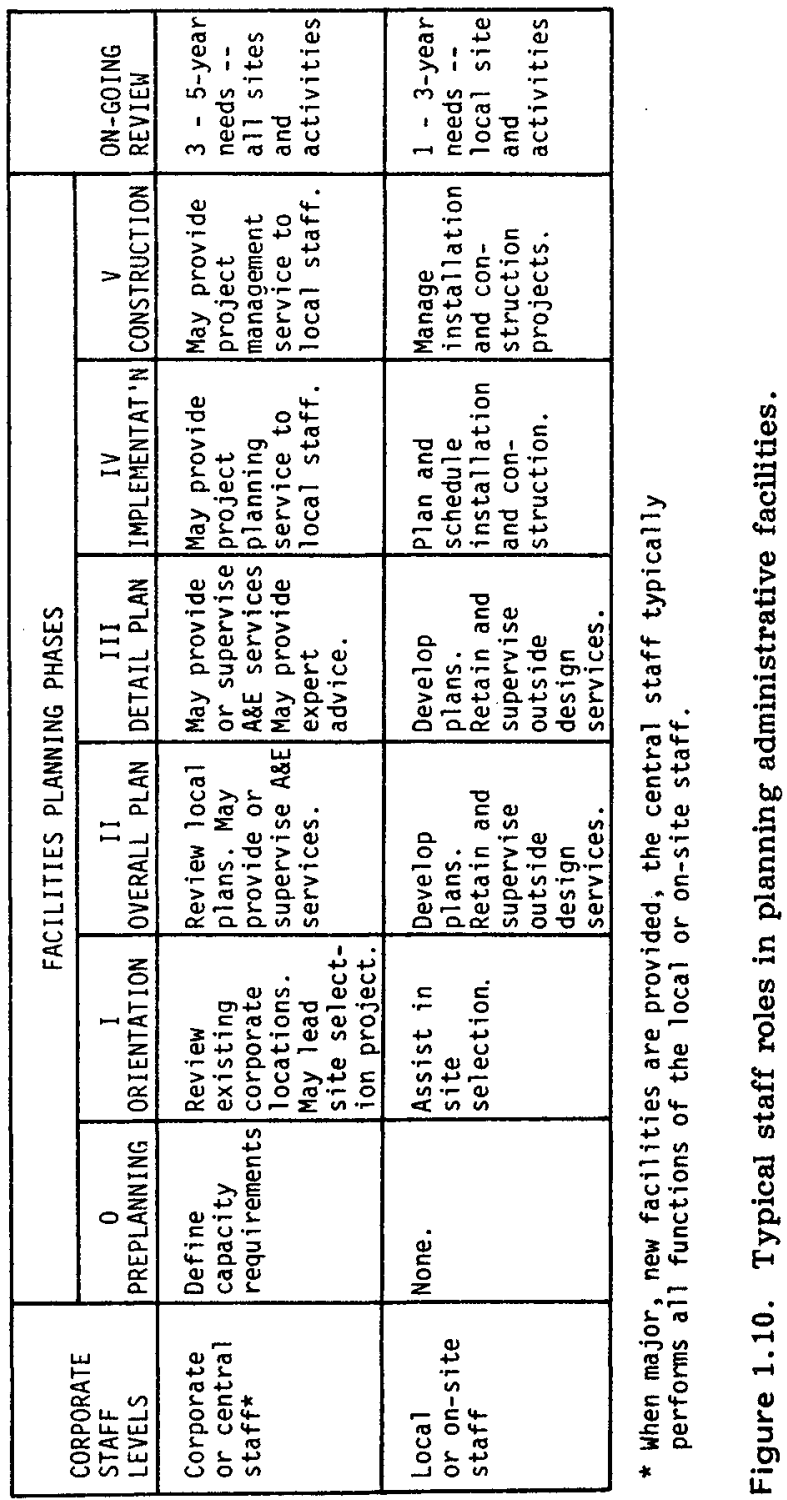


Implications for Computer Aids

Four basic questions emerge from the foregoing discussions of facilities planning. These are:

1. Which decision levels or phases do we want to support with computer aids?

2. Which components of the facility will be of greatest and most frequent concern: layout, handling, communications, utilities, buildings?

3. Which members of the planning team need computer support? Line management, staff, internal planners, external parties, headquarters, field locations--all are potential users but each may have a different need.

4. How do we provide access to potential users, recognizing that "the team" may be geographically dispersed and even international in nature?

We will return to these questions in Part II when we examine specific forms of computer support. 


\section{References}

The references below are organized into three lists, one for each part of this book.

\section{Part 1--How Facilities are Planned}

1. Apple, James M. Plant Layout and Material Handling, New York, NY, John Wiley and Sons, 1977.

2. Francis, R. L., and J. A. White. Facility Layout and Location, Englewood Cliffs, NJ, Prentice-Hall, 1974.

3. Gallagher, C. C., and W. A. Knight. Group Technology, London, England, Butterworth, 1973.

4. Lewis, Bernard T., ed. Management Handbook for Plant Engineers. New York, NY, McGraw-Hill, 1977.

5. Lewis, Bernard T., and J. P. Marron, eds. Facilities and Plant Engineering Handbook. New York, NY, McGraw-Hill, 1973.

6. Muther, Richard. Systematic Layout Planning (SLP), 2nd ed. Boston, MA, Cahners Books, 1973.

7. Muther, Richard, and Knut Haganaes. Systematic Handling Analysis (SHA), Kansas City, MO, Management and Industrial Research Publications, 1969.

8. Muther, Richard, and Lee Hales. Systematic Planning of Industrial Facilities (SPIF), Vols. I and II. Kansas City, MO, Management and Industrial Research Publications, 1980.

9. Saphier, Michael. Planning the New Office. New York, NY, McGraw-Hill, 1978. 
Part II--How Computers Can Help

10. Buffa, E. S., G. C. Armour, and T. E. Vollman. "Allocating Facilities with CRAFT." Harvard Business Review, Vol. 42, No. 2, Mar.-Apr. 1964 .

11. Burger, Amadeus M. "Computerized Plant Modeling--Practical Experiences." Construction System Associates, Inc., Marietta, GA, April 1983.

12. Carrie, A. S. "Computer-Aided Layout Planning--The Way Ahead." IE News, Facilities Planning and Design Division, Institute of Industrial Engineers, Winter, 1982.

13. "Computer-Aided Everything." Engineering News-Record, Dec. 3, 1981, reprint.

14. "Computers and the Building Team." Building Design and Construction, 1982 , collection of reprints.

15. Cytryn, Allan, and William H. Parsons. "Planning ADES, a system for Computer-Assisted Space Planning." Interior Design, May 1977.

16. Dosset, Royal. "Choosing Floppy Disk Microcomputers: A Checklist of Features for IE Applications." Industrial Engineering, Oct. 1981.

17. Dosset, Royal. "Personal Computers" What They Can Do for IEs and How to Choose One." Industrial Engineering, Oct. 1982.

18. Hales, Lee. "Computer-Aided Facilities Planning--A Brief Survey of Current Practice." Proceedings of the Numerical Control Society. Annual Technical Conference, Los Angeles, CA, 1979.

19. Hales, H. Lee, and Harvey C. Jones, Jr. "Facilities Decision Support." Master's thesis, Massachusetts Institute of Technology, 1980.

20. Horwitt, Elizabeth. "When More May Not Be Better." Business Computer Systems, Feb. 1983.

21. Hosni, Yasser A., and Timothy S. Atkins. "Facilities Planning Using Microcomputers." Proceedings of the 1983 Annual Industrial Engineering Conference, Institute of Industrial Engineers, Norcross, GA.

22. "Integrated system combines design drafting." Building Design \& Construction, July 1983.

23. Jacobs, Robert F., John W. Bradford, and Larry P. Ritzman. "Computerized Layout: An Integrated Approach to Special Planning and Communications Requirements." Industrial Engineering, July 1980.

24. Khator, Suresh, and Colin Moodie, "A Microcomputer Program for Plant Layout." Industrial Engineering, Vol. 15, No. 3, March 1983. 
25. Lee, Kaiman. "Computer Programs for A rchitects and Layout Planners." Proceedings of the American Institute of Industrial Engineers, National Conference, Boston, MA, 1971.

26. Lee, R. C., and J.M. Moore. "CORELAP-Computerized Relationships Layout Planning." Journal of Industrial Engineering, Vol. 18, No. 3, March 1967.

27. Liggett, Robin S., and William J. Mitchell. "Optimal Space Planning in Practice." Computer-Aided Design, Vol. 13, No. 5, Sept. 1981.

28. MacDonald, Joseph A., ed., Computers for Design \& Construction, Handbook 82/83 (Vol. 1, No. 1). New York, NY, MetaData Publishing, 1983.

29. Machover, Carl, and Robert E. Blauth, eds. The CAD/CAM Handbook. Bedford, MA, Computervision Corp., 1980.

30. Martin, James. Principles of Data-Base Management. Englewood Cliffs, NJ, Prentice-Hall, 1976.

31. Mitchell, William J. Computer-Aided Architectural Design. New York, NY, Mason/Charter Publishers, 1977.

32. Moore, James M. "Computer-Aided Facilities Design: An International Survey." International Journal of Production Research. Vol. 12, No. 1, Jan. 1974.

33. Moore, James M. "Computer-Aided Facilities Design: Help, Hoax or Hex." Proceedings of the American Institute of Industrial Engineers. Systems Engineering Conference, 1976.

34. Moore, James M. "Computer Program Evaluates Plant Layout Alternatives." Industrial Engineering, Vol. 3, No. 8, Aug. 1971.

35. Moore, James M. "Summary of Questionnaire on the Use of Computers in Facilities Design." AIIE Newsletter, Facilities Planning and Design Division, American Institute of Industrial Engineers, Sept. 1976.

36. Moore, James M. "Who Uses the Computer for Layout Planning?" Proceedings of the 4th International Conference on Production Research. London, England, Taylor \& Francis, 1978.

37. Moore, James M., and Yasser A. Honsi. "Can CAD/CAM?" IE News, Facilities Planning and Design Division, Institute of Industrial Engineers, Summer 1983.

38. Muther, Richard, and Kenneth McPherson. "Four Approaches to Computerized and Layout Planning." Industrial Engineering. Feb. 1970 .

39. Ritzman, L. P. "The Efficiency of Computer Algorithms for Plant Layout." Management Science, Vol. 18, No. 5, Jan. 1972. 
40. Ryan, Daniel L. Computer-Aided Architectural Graphics. New York, NY, Marcel Dekker, 1983.

41. Sato, Keiichi, and Charles L. Owen. "A Prestructuring Model for System Arrangement Problems." Proceedings of the 1980 Design Automation Conference, Association of Computing Machinery, New York, NY.

42. Seehof, J. M., and W. O. Evans. "Automated Layout Design Program." Journal of Industrial Engineering. Vol. 18, No. 12, Dec. 1967.

43. Tompkins, James A. "Computer-Aided Plant Layout." Modern Materials Handling, seven-issue series. May-Nov. 1978.

44. Tompkins, J. A., and J. M. Moore. Computer-Aided Layout: A User's Guide. American Institute of Industrial Engineers, Norcross, GA, 1978.

Part III--How to Achieve Success

45. DesRosier, G. Anthony. Implementing an Interactive Computer Graphics System: Some Initial Thoughts. Thorndale, PA, GSB Associates, 1981.

46. Keen, Peter G. W., and Michael S. Scott Morton. Decision Support Systems: An Organizational Perspective. Reading, MA, Addison-Wesley, 1973.

47. "Managing and implementing a computer system," Building Design \& Construction, July 1983.

48. "Microcomputers provide entry to computerization," Building Design \& Construction, July 1983.

49. Nilsson, John. "Analysis of Cost Benefits of Computer-Aided Design Systems" (unpublished paper). Southboro, MA, Decision Graphics, Inc., 1980 .

50. Nilsson, John. "Cost Benefit Analysis in Computer Graphic Systems" (unpublished paper). Southboro, MA, Decision Graphics, Inc., 1980.

51. Raker, Daniel S. "Can Your Vendor Support Your Low-Cost CAD System?" Plan and Print, Vol. N-55, No. 10, pp. 8-11.

52. "Selecting a computer system," Building Design \& Construction, July 1983.

53. Stasiowski, Frank A. How to Select Data Processing Systems. Dedham, MA, Practice Management Associates, 1981. 